\title{
Relation between Lactic Acid Bacteria (LAB) and C. trachomatis Infection on Infertility in Women
}

\author{
Zelly Mulyani ${ }^{1}$, Andani Eka Putra ${ }^{2}$, Arni Amir ${ }^{3}$ \\ ${ }^{1}$ Master of Biomedicine, Faculty of Medicine, Andalas University, \\ ${ }^{2}$ Department of Infectious Disease Research and Diagnostic Center Laboratory of Andalas University, \\ ${ }^{3}$ Department of Midwifery Sciences, Andalas University, Indonesia
}

Corresponding Author: Andani Eka Putra

\begin{abstract}
Infertility is one of world health problems, in which it is predicted that the case of infertility in couples of reproductive age is about $8 \%-10 \%$ or 50-80 million couples in the world. This becomes a problem, especially the factor caused in the women is of $65 \%$. Various factors cause infertility, one of which is damage to reproductive organs caused by $C$. trachomatis infection and a significant decrease in the number of Lactobacillus populations. The objective of this study was to determine the relation between $\mathrm{LAB}$ and $\mathrm{C}$. trachomatis infection on infertility in women.

This is an analytic research with a case control design of 33 women of infertile reproductive age couples and 33 women of fertile reproductive age couples. This research was carried out in the working area of the Padang Pariaman District Health Office and the Microbiology Laboratory of the Faculty of Medicine, Andalas University from June 2019 to February 2020. LAB cultures were carried out by using MRS agar and C. trachomatis media were examined by using PCR with a product length of $236 \mathrm{bp}$. The number of LAB colonies was analyzed by using Independent $\mathrm{t}$ test and data analysis on $C$. trachomatis infection by using the chi-square test.

The results showed that there was a significant difference in the number of LAB colonies on infertility in women $(\mathrm{p}=0.006)$ and there was no relation between $\mathrm{C}$. trachomatis infection and infertility in women.

The conclusion of this study is that there is a relation between the number of LAB colonies on infertility in women and there is no relation
\end{abstract}

between C. trachomatis infection and infertility in women.

Keywords: Lactic acid bacteria, Chlamydia trachomatis infection, infertility, PCR

\section{INTRODUCTION}

Infertility is a reproductive system problem indicated by the failure to get pregnant after 12 months or more having sex 2-3 times a week regularly without using contraception ${ }^{1}$. The incidence of infertility in couples of reproductive age can be caused by women or men. Based on research results, as much as $65 \%$ caused by women while $20 \%$ caused by men and $15 \%$ caused by other conditions without known cause $^{2}$. Various kinds of factors cause infertility in women such as reproductive organ abnormalities, age, stress level, weight, hormones and reproductive organ disorders such as disorders of ovulation, damage to the fallopian tubes, cervical mucus disorders, endometriosis and uterine disorders. Reproductive organ abnormalities are more at risk of infertility compared to women who do not have reproductive organ abnormalities ${ }^{3}$. Various kinds of infections caused by bacteria including Chlamydia trachomatis (C. trachomatis), Neisseria gonorrhoeae, Gardnerella vaginalis, Treponema pallidum, Klebsiella ${ }^{4}$ C. trachomatis is a sexually transmitted infection (STI) that is found in most women, and is most common in women under the age of 25 years. C. trachomatis bacteria can 

women.

cause damage to reproductive organs starting from the cervix to the upper reproductive system ${ }^{5}$

C. trachomatis is associated with a decrease in the Lactobacillus population. Lactobacillus- deficient women are at a higher risk of bacterial vaginosis and aerobic vaginitis infection, where aerobic vaginitis is a disorder caused by a lack of Lactobacillus species and an excess of aerobic bacteria such as Staphylococus spp and group streptococci. It also increases the risk of transmitting sexually transmitted diseases. Lactic acid directly prevents $C$. trachomatis infection and helps prevent other infections when the vaginal environment reaches a $\mathrm{pH}<4^{6}$

The vagina of reproductive age women is dominated by microbes that produce lactic acid, which is in the range of 107 Lactobacillus per gram of vaginal secretions. Normal vaginal flora is a normal microorganism that colonizes the vagina which can affect infertility factors due to changes in the composition of the vaginal microbiota where the depletion of Lactobacillus counts along with the development of other bacteria. The number and types of normal flora found have a significant relation to the implications for women's health, so that they can affect infertility factors in women ${ }^{7}$. The results of the research done by Sitora et al (2014) showed in women of reproductive age that bacterial vaginosis describes a disturbance in the vaginal environment that lacks Lactobacillus, and will affect the growth of pathogenic bacteria. This study explains that there is a negative effect of bacterial vaginosis on the level of conception and shows that bacterial vaginosis is significantly more prevalent in women with infertility compared to women with other causes of infertility ${ }^{8}$.

Due to several kinds of researches that have been conducted and there is no identification specifically on the number of $\mathrm{LAB}$ and $C$. trachomatis infection on the infertility on women, therefore, the researchers are interested in conducting a study regarding "The Relation between LAB and $C$. trachomatis Infection on Infertility in Women"

\section{LITERATURE REVIEW}

Basically, infertility is the biological inability of a man and a woman to have a child. In the health reproduction field, infertility indicated deficiency that does not harm individual physical integrity and does not harm individual's life. However, the deficiency can provide negative effects on individual growth, brings frustation and weakens personality, because mostly couples assume that having children as the main goal ${ }^{9}$. Meanwhile, the categories of primary and secondary infertility, primary infertility; Primary infertility means that a married couple has not been able to and have never had children after 1 year of sexual intercourse 2-3 times per week without using any form of contraception. Secondary infertility is when the wife has been pregnant before, but then there is no further pregnancy even though she has sexual intercourse without contraception and is in the possibility of getting pregnant for twelve months ${ }^{10}$.

\section{B. Chlamydia trachomatis}

Chlamydia trachomatis is the most common bacteria that is transmitted from sexual intercourse, especially in developing countries that causes genital, rectal, and ocular diseases. $C$. trachomatis was originally considered a virus because of its very small size and intracellular pathogenic life cycle ${ }^{11}$. Pathogenesis of $C$. trachomatis infection is transmitted by sexual contact. $C$. trachomatis is a strong immunogen that can stimulate cellular and humoral immune responses, thereby triggering the formation of antibodies and $\mathrm{T}$ cell activity. Its infection can be either a primary infection or a chronic infection ${ }^{12}$. Some LAB can have positive effects on health, namely stimulating local and systemic immune responses to fight pathogenic bacteria. LAB is commonly used as a probiotic to minimize intestinal diseases such as lactose intolerance, acute 
gastroenteritis, constipation, and colitis ${ }^{13}$. In a study conducted by Nikolaitchouk et al, (2009), it explained that estrogen in women is a determining factor in the sustainability of a Lactobacillus ecosystem in Indonesia. in the body that maintains the stability of the vaginal ecosystem. The conversion of glycogen to lactic acid with the help of the enzyme catalase of Lactobacillus bacteria is the key in maintaining an acidic atmosphere in the host's vagina where Lactobacillus bacteria live. The lower the Lactobacillus level, the lower the vaginal acid level, so it will be easier to get infection ${ }^{14}$.

\section{MATERIALS \& METHODS}

This is an analytic study with a case control design, namely to determine the relation between $\mathrm{LAB}$ and $\mathrm{C}$. trachomatis infection on infertility in women. This research was conducted in the Microbiology laboratory of the Faculty of Medicine, Andalas University and the working area of the Padang Pariaman District Health Office. The population in this study were all women of infertile reproductive age who visited the Microbiology Laboratory. the number of samples is at least 30 people for each group. This study was prepared with a sample reserve of $10 \%$ (3 samples) so that the total in each group became 33 samples.

Statistical Analysis [as applicable]

From the results of the study in the relation between the number of LAB colonies in infertile women, the data was not normally distributed, then the Kolmogorov Smirnov test was carried out, then the data was transformed with $\log 10$ and if the data was normally distributed, the Independent Sample t-test was performed. Analysis of data on the relation between $\mathrm{C}$. trachomatis infection and infertile women was carried out by using the Chi-square test and in the data analysis the Odds Ratio (OR) value with a $95 \%$ confidence level was calculated.

\section{RESULT}

\section{A. Frequency Distribution of Respondents Characteristics}

Table 5.1. Frequency Distribution of Respondents Characteristics

\begin{tabular}{|l|l|l|l|l|l|}
\hline \multicolumn{2}{|l|}{ Respondents Characteristics } & \multicolumn{2}{l|}{ Infertile } & \multicolumn{2}{l|}{ Fertile } \\
\cline { 3 - 6 } & & f & \% & f & $\%$ \\
\hline Age & $20-30$ & 14 & 42,4 & 20 & 60,6 \\
\hline & $31-40$ & 19 & 57,6 & 13 & 39,4 \\
\hline & Total & 33 & 100 & 33 & 100 \\
\hline Education & Low & 7 & 21,2 & 5 & 15,2 \\
\hline & Medium & 13 & 39,4 & 11 & 33,3 \\
\hline & High & 13 & 39,4 & 17 & 51,5 \\
\hline & Total & 33 & 100 & 33 & 100 \\
\hline Occupation & Not working & 14 & 42,4 & 17 & 51,5 \\
\hline & Working & 19 & 57,6 & 16 & 48,5 \\
\hline & Total & 33 & 100 & 33 & 100 \\
\hline
\end{tabular}

The frequency distribution of respondents characteristics was found at the age of 20-30 years in infertile women of $42.4 \%$ and fertile women of $60.6 \%$. Based on the frequency distribution of respondents characteristics in education, it was found that it was low-medium, showing that in infertile women, it was $21.2 \%-39.4 \%$ and in fertile women, it was $15.2 \%-33.3 \%$. Based on the frequency distribution of respondents characteristics in occupation, it was found that infertile women who work were of $57.6 \%$ and in fertile women were of $48.5 \%$.

\section{B. Number of Lactic Acid Bacterial Colonies on infertility in women}

Table 5.2 Number of Lactic Acid Bacterial Colonies on infertility in women

\begin{tabular}{|l|l|l|l|}
\hline Group & Number of LAB Colonies (Cfu/ml) & Min. & Max. \\
\hline
\end{tabular}

\begin{tabular}{|l|l|l|l|}
\hline Infertile & $7.691 \times 10^{4}$ & 4 & 709 \\
\hline Fertile & $8.603 \times 10^{4}$ & 3 & 996 \\
\hline
\end{tabular}

The calculation results of the number of Lactic Acid Bacteria colonies were the least in the inferile group $(7,691 \mathrm{x}$ $104 \mathrm{Cfu} / \mathrm{ml}$ ) compared to the fertile group $(8,603 \times 104 \mathrm{Cfu} / \mathrm{ml})$

\section{C. trachomatis Infection Proportion in Infertile Women}

Table 5.3 C. trachomatis Infection Proportion in Infertile Women

\begin{tabular}{|l|l|l|}
\hline Kelompok & F & \% \\
\hline Infertile & 2 & $33.3 \%$ \\
\hline Fertile & 4 & $66,7 \%$ \\
\hline
\end{tabular}



women.

The results showed that the infection proportion was less in the infertile group consisting of 2 respondents $(33.3 \%)$ compared to the fertile group of $66.7 \%$.

\section{The relation between the number of lactic acid bacteria on infertile women}

Table 5.4 Average Number of Lactic Acid Bacteria on Infertility

\begin{tabular}{|c|c|c|c|}
\hline Group & $\mathbf{N}$ & $\begin{array}{l}\text { Number of LAB }(\log C f u / m l) \\
(\text { mean } \pm \text { SD) }\end{array}$ & p value \\
\hline Infertile & 33 & $5,38 \pm 0,79$ & 0,006 \\
\hline Fertile & 33 & $5,93 \pm 0,75$ & \\
\hline
\end{tabular}

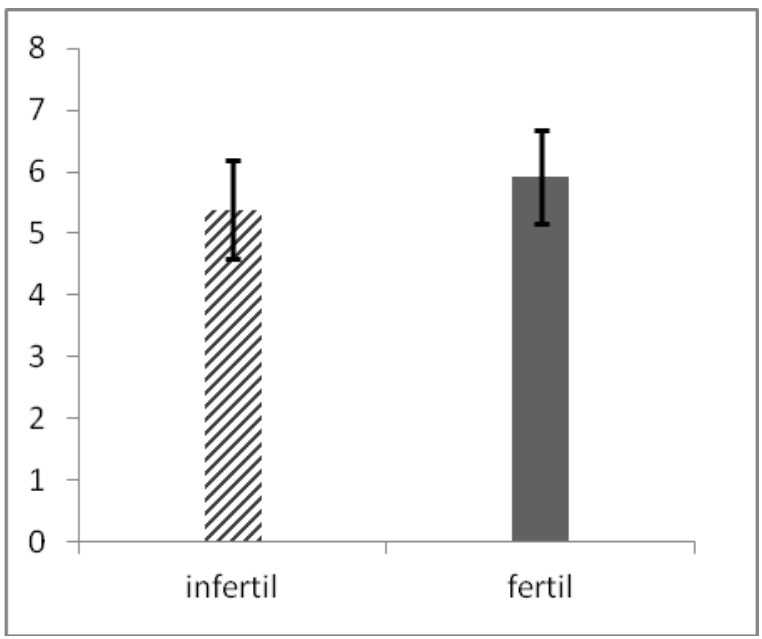

Figure 5.1 the average value of Lactat Acid Bacteria in the number of Lactat Acid Bacteria colonies on infertile and fertile woman has meaningful difference in which the value of p $<0.005$

The relation between the number of Lactic Acid Bacteria colonies and infertility in women found the average number of Lactic Acid Bacteria colonies in the infertile group was $5.38 \pm 0.79 \log \mathrm{Cfu} / \mathrm{ml}$ and in the fertile group was $5.93 \pm 0.75 \log \mathrm{Cfu} / \mathrm{ml}$. The results of the analysis using the Independent t-test showed a significant difference between the infertile group and the fertile group $(\mathrm{p}<0.05$

The average number of Lactic Acid Bacteria colonies in infertile women was $5.38 \pm 0.79 \log \mathrm{cfu} / \mathrm{ml}$, while in fertile women, it was $5.93 \pm 0.75 \log \mathrm{cfu} / \mathrm{ml}$.

\section{E. The Relation of C. trachomatis infection in infertile women}

Table 5.5 C. trachomatis Infection Proportion in Infertile Women

\begin{tabular}{|l|l|l|l|l|l|l|l|}
\hline \multirow{2}{*}{$\begin{array}{l}\text { Chlamydia } \\
\text { trachomatis } \\
\text { Infection }\end{array}$} & \multicolumn{2}{|l|}{ Infertile } & \multicolumn{2}{|l|}{ Fertile } & & & p- \\
\cline { 2 - 7 } value
\end{tabular}

Based on the results of the Chisquare test analysis, there was no relation between C. trachomatis infection and infertility in women where $(\mathrm{p}=0.672)(\mathrm{p}>$ $0.005)$. It also obtained 6 people $(9.1 \%)$ who were positively infected with $\mathrm{C}$. trachomatis including $4(12.1 \%)$ in infertile women and $2(6.1 \%)$ in fertile women.

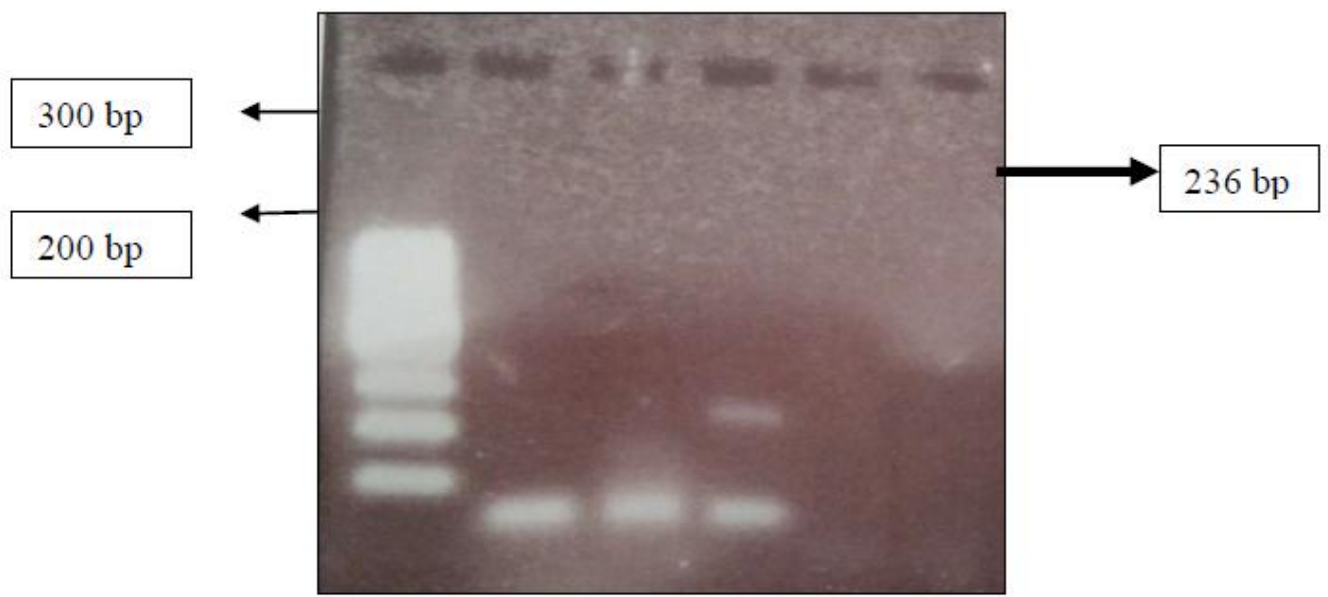

Figure 5.2 Identification of C. trachomatis by PCR

Based on the results of the $C$. trachomatis identification by PCR with a product size of 236 bp using specific primers, DNA bands appeared on gel electrophoresis indicating a positive sample of C. trachomatis. 


\section{DISCUSSION}

\section{A. Research Subjects Characteristics}

Based on the level of occupation, more than half of the respondents experienced infertility (57.6\%). There is a relation between occupation and the incidence of infertility, caused by fatigue and stress caused by the impact of work, stress caused by working mothers can cause egg cells to fail to ovulate. For some women, chronic stress can affect ovulation by changing signals in the hypothalamus, so that production can be inhibited by Gonadotropin hormone ( $\mathrm{GnRH})$, which is a hormone that functions to tell the pituitary gland to produce Luteinizing Hormone (LH) and Follicle Stimulating Hormone (FSH) hormones, which LH hormone functions to produce egg cells ${ }^{15}$

\section{B. The relation between the number of LAB in Infertile women}

The number of LAB colonies in this study showed a significant difference in the group of infertile women compared to the group of fertile women, where the value ( $p$ $<0.05$ ). This study shows that LAB is necessary to maintain a healthy condition of the vagina. The average number of LAB colonies in the fertile female group was slightly higher $5.93 \pm 0.75 \mathrm{log} \mathrm{cfu} / \mathrm{ml}$ compared to the infertile female group 5.38 $\pm 0.79 \log \mathrm{cfu} / \mathrm{ml}$.

The low number of LAB colonies in infertile women compared to fertile women indicates that $\mathrm{LAB}$ is a normal flora in the vagina which can be affected when the $\mathrm{pH}$ rises $>4$. Latic acid at physiological concentrations acidifies vaginal secretions (to a $\mathrm{pH}$ level < 4), thereby increasing the protective activity of $\mathrm{H} 2 \mathrm{O} 2$, bacteriocins and inhibiting opportunistic infections such as Trichomonas vaginalis, Neisseria gonnorrhoeae, C. trachomatis, Herpes Simplex Virus (HSV), Human Popilloma Virus (HPV) ${ }^{16}$

According to Kroon et al. (2018), the human microbiome project has demonstrated the remarkable ecological diversity of microbes in the human body.
The vaginal microbiota is most often dominated by Lactobacillus species. However, some women do not have Lactobacillus spp. and consists of a diverse range of strict and facultative anaerobes, a condition widely correlated with an increased risk of infection, disease, and poor reproductive outcomes. Interestingly, the level of protection against infection can also vary by species and strain of Lactobacillus, and some species even though dominant are not always optimal. These factors increase the risk of contracting STIs and may affect the occurrence of adverse reproductive outcomes such as tubal factor infertility. The composition and function of the vaginal microbiota are thought to play an important role in pregnancy and protect the products of conception ${ }^{17}$

\section{The Relation between $C$. trachomatis Infection and Infertile Women}

It was found from the study that there was no relation between $C$. trachomatis infection and infertile women. However, from the samples studied, it was found that $C$. trachomatis infection was more common in infertile women compared to fertile women.

There is no relation between $C$. trachomatis infection and infertility in women due to other multifactors. The results of this study are different from the research conducted by Malik et al (2012) in Aligarh on 130 infertile women, where 31 cases were found to be infected with $C$. trachomatis and there was an association between $C$. trachomatis infection and infertility. This difference in results was due to the larger number of case samples in the study of Malik et al (2012), and using the C. trachomatis examination method, it was carried out by two methods, namely culture and serology techniques ${ }^{18}$.

According to Menon et al. (2015), the interaction between pathogens and the factors causing $C$. trachomatis infection causes infertility caused by ascending infection to the upper reproductive tract in some women, resulting in tubal pathology. 
This is proven by the positive detection of C. trachomatis DNA in the endometrium, fallopian tubes, and ovaries ${ }^{19}$.

\section{CONCLUSION}

The number of LAB colonies in infertile women was $7.691 \times 104 \mathrm{Cfu} / \mathrm{ml}$,

The proportion of positive $\mathrm{C}$. trachomatis infections in infertile women is higher than in fertile women.

\section{Acknowledgement: None}

\section{Conflict of Interest: None}

\section{Source of Funding: None}

Ethical Approval: Approved

\section{REFERENCES}

1. WHO., 2009. task force: Tuba Infertility: Serology relationshop past clamydial and gonococcal infection. Sex Trans. Dis, vol. 29, h.71-7

2. Oktarina, A., Abadi, A., Bachsin, R., 2014. Faktor-Faktor Yang Memengaruhi Infertilitas Pada Wanita Di Klinik Fertilitas Endokrinologi Reproduksi. MKS. vol 46, no 4

3. Indarwati, I. Hastuti, U.R., Dewi, Y.L., 2017. Analysis of Factors Influencing Female Infertility. Journal of Maternal and Child Health, vol. 2, no. 2

4. Ochsendorf, F.R., 2008. Sexually transmitted infection: impact on male fertility. Andrologia. vol 40, no.2.

5. Harahap, S.D., et al., 2008. Hubungan Infeksi Clamydia dengan oklusi tuba pada wanita infertil. Indonesia Journal Of Obstetric and Gynecology. vol.36, h. 1011

6. Amin., Mansour., Hamed, G., Ziba., Sakineh F and Maasomeh J., 2011. Isolation and Identification of Lactobacillus species from the vagina and their antimicrobial properties, University of medical Sciences, Ahvaz, Iran. Medical Plants and Natural Products Research Center, Ahvaz Jundishapur University of Medical Sciences, Ahvaz, Iran, vol. 5, h. 3300-3304
7. Gupte, S., 2010. Mikrobiologi dasar. Terjemahan E.Suryawidjaja : The Short Textbook of Medical Microbiology. Bina Rupa Araksa. Jakarta

8. Sariroh, W dan Primariawan, R.Y., 2015. Tingginya Infeksi Chlamydia trachomatis pada Kerusakan Tuba Fallopi Wanita Infertil. Departemen Obstetri dan Ginekologi , Fakultas Kedokteran Universitas Airlangga. Vol.23, no.2

9. Ochsendorf, F.R., 2008. Sexually transmitted infection: impact on male fertility. Andrologia. vol 40, no.2.

10. (Sule, 2008)

11. Hettmann, A., Gerle, B., Barcsay, E., Csiszár, S., Takács, M., 2008. Seroprevalence Of Hsv-2 In Hungary And Comparison Of The Hsv- 2

12. Marvast, D.L., Aflatoonian, A., Talebi, A.R., Eley, A. and Pacey, A.A., 2016. Realitionship between Chlamydia trachomatis and Mycoplasma genitalium infection and pregnancy rate and outcome in Iranian infertile couple, Andrologia

13. Hestinatoro, A., dkk. 2012. Best practices on imperial (infertility, menoupause, pcos, endometriosis, recurrent miscarriage, in vitro fertilization, adolescent gynecology, luterine bleeding. Jakarta: Sagung Seto.

14. Nikolaitchouk, N., 2009. The female genital tract microbiota, University of Gothenburg, Sweden,

15. Indarwati, I. Hastuti, U.R., Dewi, Y.L., 2017. Analysis of Factors Influencing Female Infertility. Journal of Maternal and Child Health, vol. 2, no.2

16. Amin., Mansour., Hamed, G., Ziba., Sakineh F and Maasomeh J., 2011. Isolation and Identification of Lactobacillus species from the vagina and their antimicrobial properties, University of medical Sciences, Ahvaz, Iran. Medical Plants and Natural Products Research Center, Ahvaz Jundishapur University of Medical Sciences, Ahvaz, Iran, vol. 5, h. 3300-3304

17. Kroon., Samuel, J., et al., 2018. Cervicovaginal microbiota, women's health, and reproductive outcomes. Fertility and Sterility, vol. 110, no. 3.

18. Malik, A., et al., 2009. Clamydia Trachomatis Infection In Women With 
Zelly Mulyani et.al. Relation between lactic acid bacteria $(L A B)$ and c. trachomatis infection on infertility in women.

Secondary Infertility. Fertility and Sterility, h.91-5

19. Menon, S., Timms, P., Alla, J., Hocking,

J. and Huston, W.M. 2015. Human and

Pathogen Factor Associated with

Chlamydia trachomatis-Related Infertility in Women, Clinical microbiologi. Reviews. 28:962-985

How to cite this article: Mulyani Z, Putra AE, Amir A. Relation between lactic acid bacteria (LAB) and c. trachomatis infection on infertility in women. International Journal of Research and Review. 2021; 8(9): 331-337. DOI: https://doi.org/10.52403/ijrr.20210944 